\title{
METODE EKLEKTIK DALAM PEMBELAJARAN BAHASA ARAB
}

\author{
Siti Milatul Mardiyah ${ }^{{ }^{*}}$ \\ ${ }^{1}$ Sekolah Tinggi Ilmu Tarbiyah Ibnu Sina Malang
}

\begin{abstract}
Learning methodology is very necessary in the learning process. The success of a learning process also depends on the methodology, especially in learning Arabic. Many kinds of methods can be applied in teaching and learning activities, for example: lecture method, qawa'id wa al tarjamah method, preacher method, and so forth. Although there are many kinds of learning methods in learning Arabic, unfortunately there are still advantages and disadvantages of those methods. As a result of these events, the eclectic method was born, which is a combined method/mixture of methods that already existed before. This method has a goal to be achieved, namely the purpose of several methods chosen and combined, so that language skills can be collected all in this method and teaching and learning activities can run efficiently and optimally. In language learning, there is no perfect method used for various learning purposes, because the methods that can be used still have advantages and disadvantages. However, these methods can be used properly and correctly according to the needs in the learning process, so that learning objectives can be achieved. The use of methods in the learning process is adjusted to the needs of a teacher in delivering information / material to his students. So, the Arabic learning methods are chosen and used as needed, and they are not used as a whole.
\end{abstract}

Keywords: Eclectic Method, Arabic Teaching

*Korespondensi Penulis: millaasywa@gmail.com 


\begin{abstract}
Abstrak: Metodologi pembelajaran sangat diperlukan dalam proses pembelajaran. Keberhasilan suatu pembelajaran juga tergantung dari segi metodologinya, terutama dalam pembelajaran bahasa Arab. Banyak macam metode yang dapat diterapkan dalam kegiatan belajar mengajar, misalnya: metode ceramah, metode qawa'id wa al tarjamah, metode mubasyarah, dan lain sebagainya. Walaupun terdapat banyak macam metode pembelajaran dalam pembelajaran bahasa Arab, sayangnya masih terdapat kelebihan dan juga kekurangan dari metode-metode itu. Akibat dari kejadian tersebut, maka lahirlah metode elektik, yaitu suatu metode gabungan/campuran dari metode-metode yang sudah ada sebelumnya. Metode ini mempunyai tujuan yang ingin dicapai, yaitu tujuan dari beberapa metode yang dipilih dan digabungkan, sehingga keterampilan bahasa bisa terkumpul semua dalam metode ini dan kegiatan belajar mengajar dapat berjalan efisien dan optimal. Dalam pembelajaran bahasa, tidak ada suatu metode yang sempurna digunakan untuk berbagai tujuan pembelajaran, dikarenakan metode-metode yang dapat digunakan itu masih memiliki kelebihan maupun kekurangan. Akan tetapi, metode-metode itu bisa digunakan dengan baik dan benar sesuai dengan kebutuhan dalam proses pembelajaran, sehingga tujuan pembelajaran dapat tercapai. Penggunaan metode dalam proses pembelajaran disesuaikan dengan kebutuhan seorang guru dalam penyampaian informasi/materi kepada murid-muridnya. Jadi, metode-metode pembelajaran bahasa Arab itu dipilih dan digunakan sesuai kebutuhan saja, dan metodemetode itu tidak digunakan secara keseluruhan.
\end{abstract}

\title{
Kata Kunci: Metode Eklektik, Pembelajaran Bahasa Arab
}

\section{A. Pendahuluan}

Dalam mempelajari bahasa asing, sering terdengar pentingnya metodologi pembelajarannya, yang mana keberhasilan suatu program pembelajaran sering kali dinilai dari segi metode yang digunakan, terutama dalam pembelajaran bahasa. Hal ini dikarenakan, yang menentukan isi dan cara mengajarkan suatu bahasa adalah dari segi metode apa yang digunakan. Dalam pembelajaran bahasa seringkali terjadi penggunaan/penerapan sebuah metode berpindah ke metode lain, seperti halnya penggunaan suatu metode berpindah ke metode lainnya, 
selanjutnya kembali lagi menggunakan metode pertama. Perpindahan penggunaan metode tersebut terjadi, dikarenakan di dalam pengajaran bahasa terdapat banyak sekali metode-metode pengajaran yang dapat diterapkan. Dalam pembelajaran, tidak ada suatu metode yang sempurna digunakan untuk berbagai tujuan pembelajaran, dikarenakan metode-metode yang dapat digunakan itu masih memiliki kelebihan maupun kekurangan. Akan tetapi, metode-metode itu bisa digunakan dengan benar sesuai dengan kebutuhan dalam proses pembelajaran.

Seorang guru bahasa Arab harus cermat dalam memilih dan menentukan metode apa yang akan diterapkan dalam pembelajaran. Pemilihan metode yang tepat dapat menjadikan proses pembelajaran berjalan dengan baik dan optimal. Tanpa adanya penggunaan metode yang sesuai, justru akan mempersulit dalam pencapaian tujuan pembelajaran.

Salah satu metode pengajaran dalam pembelajaran bahasa Arab yang dapat digunakan yaitu dengan menggunakan metode eklektik yang disebut juga dengan Thariqah Al-Intiqaiyyah. Metode ini merupakan suatu metode pembelajaran yang terdiri dari keterampilan mendengar (istima'), berbicara (kalam), membaca (qira'ah), dan menulis (kitabah).

Metode eklektik merupakan sebuah metode pembelajaran, khususnya pembelajaran bahasa Arab untuk semua materi bahasa. Metode ini juga merupakan metode yang sempurna serta sesuai bagi orang non-Arab yang belajar bahasa. Tujuan metode eklektik adalah agar pelajar dapat memahami materimateri bahasa asing yang telah dipelajari, dapat membaca bahasa asing, dan menulisnya dengan benar. Dari pernyataan tersebut dapat disimpulkan bahwa tujuan menggunakan metode eklektik dalam pembelajaran bahasa Arab bagi siswa adalah siswa dapat menguasai empat maharah yaitu: istima', qira'ah, kalam dan kitabah dengan baik dan benar. Sedangkan tujuan dari pihak guru adalah dapat memilih dan menggabungkan beberapa metode yang dapat dan cocok digunakan dalam menyampaikan materi pelajaran yang akan disampaikan. 


\section{B. Metode Eklektik sebagai Metode Pembelajaran Bahasa Arab}

Awal mula metode pembelajaran eklektik (Thariqah Al Intiqo'iyyah) disebabkan karena banyak yang merasa tidak puas terhadap metode-metode lain yang ada sebelumnya. Metode-metode sebelumnya itu terjebak dalam kelemahan yang menjadi penyebab munculnya metode-metode baru yang datang silih berganti dengan kekuatan dan kelemahan yang dimiliki pula.

Pengajaran bahasa asing pasti menghadapi kondisi objektif yang berbedabeda di dalam lingkup yang berbeda pula. Kondisi objektif itu meliputi tujuan pengajaran, keadaan guru, keadaan siswa, keadaan sarana prasarana dan lain sebagainya yang mengalami perubahan pada satu masa ke masa berikutnya.

Berdasarkan kenyataan di atas, kemudian muncul metode baru yang bernama metode eklektik (gabungan), yang mengandung arti pemilihan dan penggabungan dari beberapa metode yang sudah ada. Dalam pembelajaran bahasa Arab, metode pembelajaran eklektik memiliki beberapa penamaan, diantaranya: الطريقة المختارة، الطريقة التوفيقية، الطريقة المزدوجة، الطريقة الانتقائية، dan sebagainya. ${ }^{1}$

Metode ini dinamakan thariqoh al-khiyariyah dikarenakan unsur-unsur yang terkandung di dalamnya merupakan gabungan dari unsur-unsur beberapa metode lain, misalnya: thariqoh al-qawaid wa al-tarjamah dan thoriqoh al-mubasyarah. Metode eklektik dalam pembelajaran bahasa Arab adalah metode pembelajaran yang lebih banyak ditekankan pada keterampilan mendengar (istima'), berbicara (kalam), membaca (qira'ah), dan menulis (kitabah). Berkenaan dengan penggunaan metode pembelajaran eklektik, patut rasanya dikenali terlebih dahulu beberapa bentuk landasan munculnya metode tersebut. Terdapat beberapa pendapat mengenai munculnya metode eklektik, diantaranya: ${ }^{2}$

\footnotetext{
${ }^{1}$ Radliyah Zaenuddin, Metodologi dan Strategi Alternatif Pembelajaran Bahasa Arab (Yogyakarta: Pustaka Rihlah Group, 2005). hal 43.

${ }^{2}$ Putri Hardiyanti, Metode Pembelajaran Elektik (Padang: Nayla Amirah, 2014). hal. 207-208.
} 
1. Metode ini mengajarkan empat maharah dalam satu jam.

2. Mengajarkan gramatika dengan bahasa tujuan.

3. Menggunakan bahasa tujuan terbatas, seperti media pembelajaran.

4. Metode ini tidak sesuai bagi orang yang ingin memahami ilmu - ilmu bahasa secara mendalam. Bahasa yang digunakan pada metode lebih terkhusus, tidak terangkum, tidak tersusun.

Metode eklektik dalam pembelajaran bahasa asing tidak terpaku pada satu metode, namun menjadikan beberapa metode untuk memberikan manfaat yang lebih. Selain yang telah dipaparkan di atas, dijelaskan pula beberapa hal yang mendasari munculnya metode pembelajaran eklektik, diantaranya:

1. Semua metode tidak ada yang ideal dikarenakan masing-masing mempunyai kelebihan dan kekurangan, dan masih berhubungan satu sama lain.

2. Suatu metode memiliki kelebihan yang bertujuan untuk mengefektifkan dan mengoptimalkan proses pembelajaran.

3. Munculnya metode baru sebagai pelengkap dan penyempurnaan dari metodemetode sebelumnya.

4. Dalam satu metode tidak ada yang diterapkan untuk semua tujuan pembelajaran.

5. Seorang guru dapat memilih metode yang sesuai dengan kebutuhan dalam proses pembelajaran.

6. Dalam suatu pengajaran, yang terpenting adalah memenuhi kebutuhan pelajar bukan memenuhi suatu metode yang digunakan.

Kebutuhan pembelajaran bahasa asing merupakan landasan pemenuhan asas yang patut menjadi perhatian oleh semua pengajar. Oleh karena itu, dibutuhkan kepiawaian seorang pengajar untuk bisa melaksanakan pembelajaran efektif dan efisien. Dalam hal ini, seorang pengajar perlu mengenali terlebih dahulu metode eklektik memiliki ciri-ciri sebagai berikut ${ }^{3}$ :

\footnotetext{
${ }^{3}$ Henry Guntur Taringan, Strategi pengajaran dan pembelajaran bahasa (Bandung: Angkasa, 1993). hal. 115.
} 
1. Pengajaran bahasa harus diterapkan dengan menggunakan bahasa target yang tepat.

2. Pengajaran bahasa harus mengandung makna dan nyata.

3. Lebih menekankan terhadap empat maharah dalam pengajaran bahasa.

4. Tidak harus menekankan pada hafalan, mimik dan mempraktekkan struktur gramatika bahasa.

Ciri-ciri tersebut harus dicermati bersama oleh pengajar sebelum menggunakan metode eklektik, hal ini diperlukan untuk lebih mengutamakan ketuntasan belajar yang sejatinya dapat diperoleh melalui penggabungan metode yang ada dengan sistem pelaksanaan yang terkombinasi dengan baik dan tepat sasaran.

Dalam pengajaran bahasa, khususnya dalam pembelajaran bahasa Arab, yang paling banyak dan sering menjadi sorotan adalah dalam penggunaan metode yang digunakan. Salah satu hal yang sering menjadi bahan perbincangan di kalangan guru maupun pelajar terkait metodologi pembelajarannya adalah dari segi materi yang dipelajari. Metodologi dengan penguasaan substansi materi yang dipelajari sangatlah erat, dan merupakan dua hal penting dalam pengajaran bahasa Arab. Pada kenyataannya setiap guru dihadapkan dengan penerapan metode-metode baru, yang kemudian dituntut agar dapat mengevaluasi pembelajaran dari hasil metode yang diterapkan itu. Begitu juga dengan metode eklektik, guru dituntut lebih profesional, kreatif, dan aktif agar dapat menggunakan metode ini dengan baik dan efisien, sehingga dapat mengevaluasi pembelajaran dari masing-masing peserta didik dengan baik, dan tujuan pembelajaran juga dapat terlaksana dengan baik pula.

Dikarenakan metode ini merupakan gabungan dari beberapa metode sebelumnya, maka cara penggunaan dan penerapannya juga terdapat perbedaan pula. Di samping menguasai materi yang diajarkan, seorang guru juga harus dapat memahami dan menguasai bagaimana cara menyampaikan materi yang diajarkan kepada muridnya, agar apa yang disampaikan oleh guru tersebut dapat diterima, dicerna dan dipahami oleh murid dengan baik dan benar. Murid juga tidak 
merasakan kebingungan dan kesulitan saat memahami materi yang diajarkan. Dalam metode eklektik ini, murid juga lebih dituntut untuk lebih kreatif, aktif dan tidak monoton dalam pembelajaran, sehingga suasana di dalam kelas lebih hidup, nyaman dan kondusif. Hal-hal lain yang terkait dalam penerapan metode eklektik meliputi berbagai aspek. Beberapa pertimbangan dalam penilaian penggunaan metode eklektik meliputi4:

1. Kemampuan guru

Keberhasilan pencapaian tujuan pembelajaran dan penerapan metode sangatlah dipengaruhi oleh kemampuan seorang guru. Penguasaan guru terhadap materi yang diajarkan merupakan penyelesaian dalam tahap pertama bagi seorang guru. Selanjutnya guru harus dapat memilih dan menggunakan metode yang sesuai dengan materi yang diajarkan agar proses pembelajaran lebih mudah, efisien, dan efektif. Penguasaan materi pelajaran dan didukung dengan metode yang sesuai mempermudah guru untuk mentransfer ilmu/materi yang diajarkan kepada muridnya dengan mudah dan baik.

2. Anak didik

Setiap murid/pelajar memiliki karakter, keterampilan, kemampuan, kecerdasan, latar belakang ekonomi dan sosial yang berbeda-beda. Dalam memilih dan menggunakan metode hendaklah hal-hal tersebut perlu dipertimbangkan lagi agar materi dengan mudah tersampaikan, dan lebih mudah dipahami oleh murid.

3. Tujuan

Tujuan yang harus dicapai dalam suatu pembelajaran turut andil dan saling berhubungan dengan metode yang digunakan. Seorang guru harusnya dapat memilih dan menggunakan metode yang sesuai dengan materi yang diajarkan guna agar tercapai tujuan pembelajaran yang dimaksud.

4. Fasilitas

${ }^{4}$ Anwar Abd Rahman, "Pengajaran Bahasa Arab dengan Metode Eklektik," Jurnal Adabiyah 11, no. 1 (2011): 65-74. 
Adanya fasilitas (sarana prasarana) yang memadai juga turut ikut membantu mempermudah memperjelas informasi penyajian materi yang diajarkan dalam kegiatan belajar mengajar maupun tujuan pembelajarannya.

5. Waktu

Alokasi waktu sangat berkaitan dengan metode yang digunakan seorang guru dalam proses pembelajaran. Hendaknya guru mempertimbangkan metode yang sesuai dengan alokasi waktu yang tersedia. Apabila metode yang digunakan tidak sesuai dengan alokasi waktu maka proses pembelajaran tidak akan bisa berlangsung dengan baik, dan tujuan pembelajaran akan sulit dicapai. Hal tersebut dikarenakan seorang guru tidak bisa optimal menyampaikan materi dan materi tidak sepenuhnya bisa diterima oleh murid atau murid kesulitan memahami materi pelajaran. Sehingga dalam hal ini beresiko akan timbulnya kegagalan seorang guru dalam mengajar, penerapan suatu metode tidak terpenuhi dan tujuan pembelajaran juga tidak bisa tercapai.

6. Situasi dan kondisi

Dalam hal situasi dan kondisi yang dimaksud disini adalah keadaan gedung sekolah, ruang kelas, lingkungan sekitar sekolah guru, dan murid saat berlangsungnya kegiatan belajar mengajar di sekolah.

7. Kelebihan dan kekurangan suatu metode

Dari sekian banyak metode, pastilah memiliki kelebihan dan kekurangan. Dalam kurun suatu waktu, suatu metode dianggap mempunyai kelebihan, di waktu lain metode tersebut bisa jadi dianggap mempunyai kelemahan. Hal tersebut dijadikan anggapan bahwa metode yang sesuai dipilih oleh guru, dan metode yang kurang sesuai ditinggalkan guru. Dengan demikian, dapat diambil kesimpulan bahwa antar satu metode dengan metode lain saling berkaitan, dan tidak jarang bahwa seorang guru sering mengkombinasi/mencampur metode satu dengan metode lainnya sesuai dengan kebutuhan dalam proses pembelajaran agar penyampaian materi dapat tersalurkan lebih mudah, efektif dan efisien. 
Ada beberapa faktor yang perlu dipertimbangkan dalam memilih suatu metode dalam pengajaran bahasa asing. Seorang guru alangkah baiknya jika mengetahui faktor-faktor tersebut sebelum menyampaikan materi yang akan diajarkan kepada murid-muridnya. Penguasaan guru terhadap faktor-faktor tersebut dapat membantu dan mempermudah guru untuk merancang, menyampaikan, menjelaskan dan mengevaluasi penggunaan metode yang sesuai dengan proses pembelajaran yang dihadapinya. Faktor-faktor tersebut adalah sebagai berikut:

\section{Latihan guru}

Seorang guru yang tidak mempunyai persiapan atau belum mempelajari dan memahami suatu metode yang akan digunakan maka ia akan mengalami kesulitan ketika menggunakan/menerapkan metode tersebut di dalam kelas.

2. Kebiasaan guru

Seorang guru yang hanya terbiasa menggunakan satu metode saja dalam jangka waktu yang lama dan tidak pernah mencoba menggunakan metode baru lainnya, maka ia akan kesulitan mengganti metode yang biasa ia gunakan. Guru tersebut akan merasa keberatan dan kesulitan akan lahirnya metode-metode baru jika ia tidak membiasakan diri pribadinya untuk menghadapi dan mempelajari metode-metode lainnya itu.

3. Kepribadian guru

Kebanyakan yang terjadi pada para guru yakni mengalami perbedaan kemampuan menggunakan metode tertentu. Sebagian guru sudah cocok dan menguasai suatu metode, padahal guru yang lain belum tentu cocok menggunakan metode tersebut. Demikian juga sebagian guru tersebut belum tentu menguasai metode-metode lain selain metode yang sering digunakan itu. hal ini mengakibatkan guru terjebak untuk menggunakan metode tertentu dan tidak bisa menggunakan metode lainnya. Misalnya saja seorang guru yang pemalu, maka ia akan memilih metode yang jarang berinteraksi dengan para pelajar. 


\section{Motivasi guru}

Seorang guru yang malas dan kurang semangat dalam mengajar, maka akan berpengaruh pada proses belajar mengajar, dan hasilnya tidak akan berjalan efektif dan optimal. Sama halnya penggunaan metode baru juga menjadi lemah karena dipengaruhi oleh seberapa besar motivasi seoang guru terhadap metode tersebut dan sikapnya dalam proses pembelajaran.

5. Beban guru

Apabila keadaan guru dalam mengajar dalam kondisi kurang prima maka sebaiknya guru memilih dan menggunakan metode yang tidak memerlukan banyak energi. Kebanyakan guru tidak menganggap pemilihan penggunaan metode sebagai pengurangan beban akan dirinya, sedikit sekali keefektivitasnya dibandingkan dengan beristirahat.

6. Cara belajar guru

Kebanyakan para guru memilih dan menggunakan metode sebagaimana ia belajar dahulu. Seakan-akan ia berkata: "Belajarlah sebagaimana saya belajar waktu di sekolah dulu". Jarang seorang guru berpikir bahwa kemajuan dan perkembangan tekonologi juga mempengaruhi proses belajar mengajar, dan hal ini juga berpengaruh pada pemilihan metode yang semakin lama semakin maju dan berkembang. Keberhasilan tujuan pembelajaran yang ingin dicapai pada masa kini juga banyak tergantung pada bagaimana cara guru yang mengajarinya dan keterampilan menggunakan teknologi yang tersedia yang sesuai dengan materi yang diajarkan.

7. Usia pelajar

Faktor usia pelajar juga sangat berpengaruh terhadap pemilihan dan penggunaan metode pembelajaran. Misalnya saja, metode pembelajaran yang digunakan untuk pelajar SD/MI belum tentu cocok digunakan untuk pelajar SLTP/MTS, demikian pula sebaliknya metode yang digunakan pelajar SLTP/MTS belum tentu cocok digunakan untuk pelajar SD/MI. Kebanyakan untuk pelajar SD/MI lebih cocok menggunakan metode drill dan peniruan, sedangkan untuk 
pelajar SLTP/MTS lebih cocok menggunakan metode yang mengandung penafsiran logika dan pola-pola ilmu nahwu misalkan.

8. Minat pelajar

Seorang guru hendaklah bisa mendorong dan membangkitkan minat pelajar dalam mempelajari bahasa asing, khususnya bahasa Arab. Dikarenakan jika seorang pelajar semangat dan menyukai pelajaran yang ia pelajari, maka akan semakin mudah ia memahami dan mengusai pelajaran tersebut, dan guru tidak akan kesulitan dan bersusah payah untuk mengajarinya. Sebaliknya jika pelajar sudah malas, tidak senang dan tidak mempunyai rasa semangat sama sekali dalam mempelajarinya, maka pasti ia akan mengalami kesulitan dan kebosanan dalam mempelajari dan memahami pelajaran tersebut, dan akibatnya guru juga akan kesulitan dalam proses pembelajaran dan tujuan pembelajaran juga tidak akan tercapai dengan baik.

9. Harapan para pelajar

Para pelajar tentu memiliki harapan-harapan tertentu ketika mempelajari bahasa asing, khususnya bahasa Arab. Hal ini berpengaruh pada strategi, pendekatan, teknik dan metode apa yang digunakan guru dalam proses pembelajarannya. Harapan-harapan mereka terbentuk dari pengalamanpengalaman mereka selama proses pembelajaran yang sama pada masa-masa sebelumnya, kebiasaan-kebiasaan belajar mereka, dan kebutuhan-kebutuhan mereka. Seorang guru hendaklah menuntun, mengubah dan membimbing mereka ke arah yang lebih baik lagi agar mereka dapat mencapai harapan-harapan mereka dengan baik dan terarah.

10. Kecerdasan pelajar

Hasil dari beberapa penelitian menunjukkan bahwa kecerdasan seorang pelajar sangat berhubungan dan berpengaruh terhadap kemampuan belajar bahasa asing, khususnya bahasa Arab. Dengan adanya beberapa penelitian ini dapat diambil kesimpulan bahwa metode yang digunakan untuk anak yang ber-IQ 
tinggi berbeda dengan metode yang digunakan untuk anak yang ber-IQ standart dan juga metode yang digunakan untuk anak yang ber-IQ di bawah normal.

11. Media pengajaran

Terdapat perbedaan yang mencolok antara penggunaan media dalam proses pembelajaran, misal dengan kaset, LCD, film, laboratorium, kartu-kartu, gambar dan lain sebagainya dengan proses pembelajaran tanpa menggunakan media. Penggunaan media pembelajaran sangat berpengaruh terhadap efisiensi dan keefektifitasan metodologi pembelajaran.

\section{Tujuan pengajaran}

Tujuan suatu pembelajaran sangat berpengaruh terhadap metodologi yang dipilih dan digunakan seorang guru untuk mencapai tujuan tersebut. Metode yang digunakan haruslah sesuai dan sejalan dengan tujuan pembelajaran. Misalnya saja, tujuan pembelajarannya untuk maharah kalam, maka metode yang digunakan harus sesuai dengan maharah kalam, misalnya menggunakan metode mubasyarah (langsung) dan metode drill.

13. Hubungan antara bahasa ibu dan bahasa asing

Dua bahasa yang berbeda yakni bahasa ibu (bahasa asal) dengan bahasa asing (bahasa yang dipelajari) memiliki berbagai aspek yang berbeda-beda dan juga berbagai kendala untuk mempermudah memahami bahasa asing yang diajarkan tersebut. Misalnya saja, seorang guru dituntut untuk meninggalkan bahasa ibu dalam proses pengajarannya dengan menggunakan metode mubasyarah, hal ini kebanyakan merupakan tantangan dan kesulitan bagi seorang guru dan juga siswa-siswanya dikarenakan kurang terbiasa dan ketidaksiapan pelajar meninggalkan bahasa ibu dalam proses pembelajaran, serta kurangnya penguasaan terhadap bahasa asing yang dipelajarinya.

14. Lamanya program pembelajaran

Lamanya program pembelajaran yang berdurasi pendek otomatis tujuan yang akan dicapai juga terbatas. Oleh sebab itu kebanyakan tujuan pembelajaran hanya memfokuskan terhadap beberapa keterampilan berbahasa saja. Apabila 
durasi waktu pembelajaran itu bisa diperpanjang maka tujuan pembelajaran juga dapat bertambah dan mencakup berbagai hal tentang kemampuan dan kemahiran berbahasa.

\section{Jumlah pelajar setiap kelas}

Aspek metode yang digunakan seorang guru juga berpengaruh terhadap seberapa banyak jumlah siswa yang ada di setiap kelasnya. Terdapat beberapa metode yang berhasil digunakan di kelas yang siswanya berjumlah sedikit, dan tidak berhasil atau tidak cocok digunakan di kelas yang siswanya berjumlah besar. Seorang guru mungkin saja akan merasa berat dan kesulitan menggunakan metode tersebut dalam kelas besar, akan tetapi merasa mantap dan ringan ketika dia mengajar di kelas kecil.

16. Test

Para guru dan para pelajar kebanyakan memprioritaskan pada mata pelajaran yang diujikan, terutama pada ujian akhir tahun. Pada mata pelajaran yang tidak ada ujiannya, kebanyakan para guru dan pelajar otomatis juga kurang memperhatikannya. Dengan demikian, hal tersebut akan mengalami timbal balik bagi guru dan pelajar dalam penggunaan metode yang dipilih dan digunakan. Sama halnya dengan kualitas tes juga sangat berpengaruh dengan hal-hal tersebut.

Dari paparan faktor-faktor di atas dapat diambil gambaran bahwa seorang guru hendaklah mengetahui, menguasai faktor-faktor tersebut dan selalu siap sedia pada hal-hal yang akan terjadi ketika proses pembelajaran berlangsung. Faktor-faktor tersebut juga bisa menjadi titik acuhan seorang guru dalam menentukan dan menggunakan metode pembelajaran, yang mana dalam situasi tertentu guru tidak bisa menggunakan suatu metode dan bisa menggunakan metode lainnya yang sesuai sebagai alternatif keefektifan proses pembelajaran ${ }^{5}$. Guru harus bisa mengubah pola dan bentuk metode yang disesuaikan dengan kebutuhan, situasi dan kondisi siswa serta lingkungan sekitar sekolah. Dan

\footnotetext{
${ }^{5}$ Yayan Nurbayan, Metodologi Pembelajaran Bahasa Arab (Bandung: Zein Al Bayan, 2008). hal 24-28.
} 
sangatlah buruk jika seorang guru hanya menggunakan satu metode saja untuk semua tujuan dan situasi pembelajaran, dikarenakan satu metode tidak bisa mencakup semua tujuan pembelajaran.

Pelaksanaan pembelajaran bahasa Arab yang memperhatikan penggunaan metode eklektik perlu mengenali asumsi kenapa pengajar harus mempertimbangkan metode ini dalam pembelajaran bahasa Arab. Dalam pada itu terdapat beberapa asumsi yang menjadi pertimbangan penggunaan metode eklektik yang merupakan penggabungan beberapa metode sebagai berikut 6 :

1. Setiap metode dapat disimpulkan aspek-aspek positifnya yang serasi dan tidak bertentangan.

2. Tidak ada suatu metode yang sesuai untuk semua tujuan pembelajaran, semua program pembelajaran, semua guru maupun semua murid.

3. Setiap metode pasti mempunyai kelebihan yang dapat digunakan dan dimanfaatkan dalam pengajaran bahasa asing, terutama dalam pengajaran bahasa Arab. ${ }^{7}$

4. Tidak ada metode yang sempurna ataupun metode yang salah, akan tetapi setiap metode pasti mempunyai kelebihan dan juga kekurangan masingmasing. Dan dari kelebihan metode tersebut dapat diambil manfaatnya untuk lebih mengefektifkan proses pembelajaran.

5. Setiap metode mempunyai karakteristik, latar belakang, dasar pemikiran yang berbeda-beda, bahkan bisa jadi kemunculan metode baru dikarenakan ketidakcocokan dalam penggunaan metode sebelumnya. Dan dari masalah tersebut dapat diambil ikhtisar bahwa jika metode-metode yang sudah ada tersebut kemudian digabungkan menjadi satu, digunakan sesuai kebutuhan

${ }^{6}$ Ahmad Rifa'i. Implementasi Thariqah Al Intiqaiyyah (Metode Eklektik) Pada Pembelajaran Bahasa Arab Di MTsN Kediri 1. Realita: Jurnal Penelitian dan Kebudayaan Islam. Vol 13 No. 2 (2015). hlm. 165.

${ }^{7}$ Anwar Abd Rahman, "Pengajaran Bahasa Arab dengan Metode Eklektik," Jurnal Adabiyah 11, no. 1 (2011): 70. 
dalam pengajaran, maka antar setiap metode yang digabungkan dapat saling menyempurnakan satu sama lain.

6. Dalam pengajaran yang terpenting yaitu memberikan perhatian kepada murid dan juga memenuhi kebutuhan setiap murid yang berbeda-beda, bukannya memenuhi metodenya saja.

7. Lahirnya metode baru sebagai penyempurna terhadap metode lama yang kurang tepat.

8. Seorang guru berhak/bebas menentukan dan menggunakan teknik-tenik dan langkah-langkah metode apa yang mau dipakai yang sesuai dengan kebutuhan pelajar dalam proses pembelajaran.

Metode eklektik bisa menjadi metode yang ideal apabila didukung oleh profesionalisme seorang guru, ketrampilan, dan penguasaan penggunaan terhadap berbagai metode. Yang mana ia bisa mengambil dari segi-segi kelebihan suatu metode dan menggunakan metode yang sesuai dengan materi yang diajarkan, kemudian menerapkan metode tersebut secara proposional.

Apabila metode eklektik digunakan semau guru saja dan pemilihan metode hanya sebatas selera guru atau yang dirasa paling mudah digunakan, maka akibatnya proses pembelajaran berakhir tidak menentu dan sulit mencapai tujuan pembelajaran yang diharapkan.

Penggabungan penggunaan antar metode itu tidaklah hanya dilakukan semaunya saja, melainkan digabungkan karena kebutuhan dalam proses pengajaran. Penggabungan ini dilakukan antar metode yang sehalauan saja dan tidak digabungkan pada antar metode yang saling bertolak belakang. Penggabungan metode juga digunakan dengan teknik-teknik atau operasional tertentu yang sesuai dengan kebutuhan. ${ }^{8}$

${ }^{8}$ Ahmad Rifa'i, Implementasi Thariqah Al Intiqaiyyah (Metode Eklektik) Pada Pembelajaran Bahasa Arab Di MTsN Kediri 1. Realita: Jurnal Penelitian dan Kebudayaan Islam. Vol 13 No. 2 (2015). hal. 166. 


\section{Rancangan dan Proses Penggunaan Metode Eklektik Dalam PBA}

Metode eklektik lebih meninjau pada ketidakpuasan terhadap metodemetode yang sudah ada sebelumnya, yang mana masing-masing dari metodemetode tersebut memiliki kelebihan dan juga kelemahan. Dikarenakan hal tersebut, kebanyakan orang berasumsi bahwa dengan menggabungkan metodemetode yang sudah ada sesuai dengan kebutuhan dalam proses pengajaran akan membantu mempermudah guru dalam menyampaikan materi, serta pembelajaran menjadi lebih efektif. Adapun karakteristik metode eklektik adalah sebagai berikut ${ }^{9}$ :

1. Kegiatan belajar di kelas bisa berupa latihan (oval practice), membaca keras (reading aloud) dan tanya jawab

2. Kemahiran berbahasa diajarkan dengan urutan bercakap, menulis, membaca dan memahami.

3. Dalam metode ini juga terdapat latihan menerjemahkan pelajaran gramatika secara dedukatif

4. Digunakan alat-alat atau audio visual

Karakteristik yang disebutkan di atas memberi gambaran bahwa di dalam penggunaan metode eklektik terdapat gabungan dari beberapa keterampilan metode-metode sebelumnya.

Karakteristik yang telah dibangun melalui latihan yang efektif dan efisien serta adanya pesan yang dibangun baik melalui tulisan dan lisan akan memberikan makna yang selaras dengan pencapaian tujuan pembelajaran. Dalam pada itu, teknik tanya jawab secara simultan, akan turut membantu tersampaikannya tujuan pembelajarannya. Proses pembelajaran bahasa Arab yang mana pelaksanaannya membutuhkan perancangan yang tepat diantaranya: ${ }^{10}$

${ }^{9}$ Muljanto Sumardi, Pedoman Pengajaran Bahasa Asing (Surabaya: CV. Ilmu Surabaya, 2007). hal. 37.

${ }^{10}$ Raswan. Pengaruh Metode Pembelajaran Eklektik Terhadap Hasil Belajar Bahasa Arab Siswa. Arabiyat: Jurnal Pendidikan Bahasa Arab. Vol. 5 No. 1 Tahun 2018: 129-130. 
1. Materi Ajar Bahasa Arab. Materi ajar bahasa Arab meliputi: topik materi ajar, desain yang menggambarkan kegiatan pembelajaran. Topik materi ajar bahasa Arab yang efektif adalah topik-topik kontekstual dan komunikatif tentang tema keagamaan, kepribadian, keseharian, dan iptek.

2. Desain pembelajaran bahasa Arab. Desain pembelajaran bahasa Arab terdiri atas:

a. Maharah istima' dan maharah kalam (keterampilan mendengar dan keterampilan berbicara) meliputi:

1) teks percakapan yang komunikatif dan kontekstual atau berupa LCD

2) mufradat

3) latihan (تدريبات), contoh: bercakaplah seperti contoh ( أجر الحوار كما فى (المثال), rubahlah seperti contoh (حوّل كما فى المثنال), gantilah seperti contoh (إستبدل كما فى المثال).

4) Permainan bahasa (العاب لغوية)

5) Tugas wajib

b. Maharah qira'ah dan maharah kitabah (keterampilan membaca dan keterampilan menulis) meliputi:

1) Teks bacaan yang pragmatik, komunikatif, dan kontekstual

2) Contoh-contoh teks yang komunikatif, struktural, dan kontekstual

3) Mufradat

4) Penjelasan dan kesimpulan (oleh guru atau siswa)

5) Latihan membaca

a) Bacalah dengan membunyikan semua baris akhirnya secara jelas

b) Terjemahkan teks/bacaan ke dalam bahasa Indonesia

c) Buatlah kesimpulan teks/bacaan

d) Sebutkan jenis kata yang digarisbawahi

e) Jelaskan terjadinya perubahan akhir pada kata yang bergaris bawah 
f) Jelaskan i'rab kata-kata yang bergaris bawah dan alasannya (setelah siswa paham dan menguasai materi yang dipelajari tersebut)

g) Tugas wajib.

Perancangan yang disusun berdasarkan konsep di atas, akan memberikan dampak yang sangat signifikan dalam tumbuh kembang peserta didik dalam membangun konsep dan menuangkannya dalam proses pembelajaran bahasa Arab yang mempertimbangkan penggunaan metode eklektik. Penggunaan metode yang tepat sesuai dengan arahan yang tepat pula, maka akan memberikan dan membentuk pola yang tepat pula untuk keberhasilan pembelajaran.

Menggunakan metode eklektik dalam pembelajaran bahasa asing, terutama bahasa Arab yaitu memanfaatkan kelebihan-kelebihan yang dimiliki metode tersebut untuk mengatasi kekurangan-kekurangan yang terdapat di dalamnya. Misalkan seorang guru ingin melatih kemampuan siswa-siswa untuk memahami teks bacaan beserta gramatika yang terkandung di dalamnya, juga melatih kecakapan siswa dalam berbicara bahasa Arab, maka guru tersebut dapat menggunakan metode eklektik (gabungan) yang terdiri dari metode qawa'id wa at tarjamah, metode qira'ah, drill, dan diselingkan juga dengan metode mubasyarah (langsung) untuk melatih berbicara secara langsung.

Langkah yang dapat dilakukan dalam proses pembelajaran tersebut adalah dengan menggunakan metode yang fleksibel, misalnya sebagai berikut ${ }^{11}$ :

1. Pendahuluan pembelajaran (sebagaimana pendahuluan dalam metode-metode lain).

2. Guru menyuguhkan materi yang mudah dipahami. Mula-mula materi disajikan dengan lisan yang diiringi isyarat, gerakan gambar atau dramatisasi. Misalnya berupa dialog-dialog pendek dengan menggunakan tema kegiatan sehari-hari, yang diterapkan secara berulang.

${ }^{11}$ Acep Hermawan, Metodologi pembelajaran bahasa Arab (Bandung: PT Remaja Rosdakarya, 2011). hal. 198-199. 
3. Guru mengarahkan para pelajar agar menyimak dialog-dialog tersebut, lalu menirukan apa yang didengar sampai benar-benar lancar.

4. Guru membimbing para pelajar untuk mengimplementasikan dialog-dialog itu bergantian dengan teman-temannya.

5. Setelah memperagakan dialog-dialog tersebut sesama teman, guru memberikan teks bacaan lain, yang temanya masih berkaitan dengan dialog yang dipelajari tadi. Kemudian guru memberikan contoh bagaimana cara membaca yang baik dan benar, serta diikuti oleh para pelajar berulangkali.

6. Apabila di teks bacaan tersebut terdapat kosa kata yang baru dan sulit, guru mengajarinya dengan cara memberitahu dengan gerakan, atau isyarat, atau gambar atau lain-lainnya. Apabila cara tersebut pelajar belum juga paham, maka guru menerjemahkan dengan menggunakan sinonimnya atau bahasa populer.

7. Guru mengenalkan beberapa struktur gramatika yang terkandung pada teks, kemudian membahasnya bersama-sama.

8. Guru memberi tugas untuk menelaah teks yang telah dipelajari, kemudian mendiskusikan isi yang terkandung di dalamnya.

9. Penutup pembelajaran, yaitu dengan memberikan evaluasi berupa pertanyaan-pertanyaan tentang isi teks yang dibahas. Hal ini dapat dilakukan secara individu maupun kelompok, sesuai dengan kebutuhan. Guru juga dapat memberi tugas yang harus dikerjakan di rumah, apabila masih memiliki waktu untuk mengerjakan.

Tahapan yang dilalui dalam penggunaan metode eklektik, akan memberikan model bagaimana seharusnya pembelajaran bahasa Arab yang sesuai dengan karakteristiknya, berikut ini adalah contoh dari penerapan metode eklektik, yaitu:

1. Guru menggunakan teks percakapan/bacaan dalam pembelajaran, lalu membacakannya kepada siswa.

2. Guru menyuruh siswa untuk membaca teks percakapan/bacaan tersebut dengan suara keras/nyaring. 
3. Guru memberikan mufradat baru seputar hiwar/bacaan yang dipelajari dan menuliskannya di papan tulis, serta dapat menambahkan sinonim ataupun antonimnya, misalnya: dalam tema yang dibahas terdapat 6 atau lebih mufradat baru.lalu siswa wajib menghafal mufradat tersebut.

4. Guru memberi tugas soal-soal (tadribat) seputar teks. Soal (Tadribat) terdiri dari tadribat syafahi dan tadribat kitabah. Tadribatsyafahi misalnya: mengulangi kalimat, menjawab pertanyaan, mengimplementasikan hiwar atau yang lainnya. Tadribat kitabah, yaitu: menuliskan huruf, melakukan imla', menjawab pertanyaan ataupun yang lainnya.

5. Setelah mengerjakan soal, guru menggunakan metode yang sesuai untuk menjelaskan susunan gramatika yang terdapat di dalam teks.

Di akhir pembelajaran, guru memberikan latihan/soal di luar teks dengan tujuan agar siswa dapat memahami materi yang diajarkan dengan baik dan tepat. Tadribat syafahi dan kitabiyyah juga dapat diterapkan berupa pekerjaan rumah (PR).

Langkah pembelajaran bahasa Arab yang menimbang penggunaan metode eklektik, dapat tersaji melalui identifikasi peserta didik yang tepat sehingga proses pembelajaran dapat dipantau dan diberikan rekomendasi untuk keberlanjutan pencapaian tujuan yang diharapkan.

Penggunaan metode eklektik dalam pembelajaran bahasa Arab akan mengalami adaptasi dalam suatu hal baru, maka diperlukan pengetahuan akan contoh-contohnya. Adapun bentuk-bentuk metode eklektik dalam pembelajaran bahasa Arab diantaranya sebagai berikut:

1. Beberapa ahli pengajaran bahasa asing yakni Eropa dan Amerika menyarankan beberapa metode yang dapat digunakan untuk menyelesaikan latihan-latihan manipulatif dengan latihan-latihan komunikatif. Paulston (1971) mengenalkan tiga corak metode drill yaitu: manipulatif - bermakna komunikatif. Rivers (1973) menggunakan istilah lain yaitu: manipulatif - semi komunikatif - komunikatif. Contoh: 
a. Drill manipulatif:

$$
\begin{aligned}
& \text { محمد يرجع من المدرسة ب..... السيارة } \\
& \text { الأوتوبيس }
\end{aligned}
$$

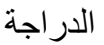

$$
\begin{aligned}
& \text { الطائرة }
\end{aligned}
$$

b. Drill semi komunikatif:

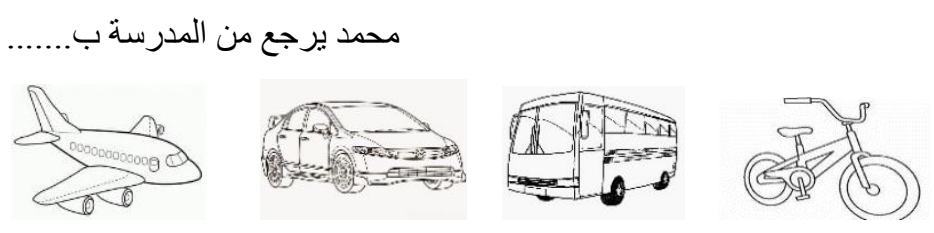

c. Drill komunikatif:

$$
\begin{aligned}
& \text { المعلم : أنا أرجع من المدرسة بالسيارة، وأنت يا محمود؟ }
\end{aligned}
$$

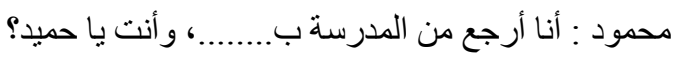

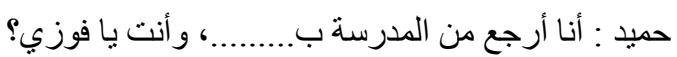

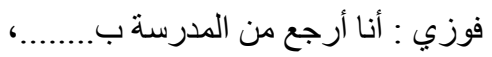

2. Sadtono (1978) menyarankan agar jumlah manipulatif dan komunikatif dalam pengajaran bahasa diatur secara gradual sesuai dengan tingkat/level pembelajaran yang diikuti siswa.

3. Modifikasi dan pengembangan bahan ajar, misalnya saja dalam materi percakapan misal berbentuk dialog untuk dihafalkan, kemudian ditambah atau dikembangkan dengan materi yang lebih konseptual dan konkrit. Dalam materi tata bahasa induktif menjadi deduktif, pengetahuan menjadi penerapan. Materi bacaan yang dalam audiolingual ditekankan pada pelafalan dan penguasaan pola-pola kalimatnya, dikembangkan dengan latihan-latihan analisis model metode membaca dan seterusnya. Dalam materi tata bahasa induktif menjadi deduktif, pengetahuan menjadi penerapan.

4. Penyingkatan jarak waktu antara latihan manipulatif dan latihan komunikatif. Dalam audio lingual murni, latihan-latihan manipulatif mekanistis bisa berjalan lebih dari 16 minggu, baru setelah jangka waktu tersebut bisa 
diberikan latihan komunikatif. Dalam metode eklektik jarak waktu bisa dipersingkat lagi.

Bentuk-bentuk penggabungan lain bisa berupa penambahan jumlah latihan qira'ah dan kitabah, yang mana di dalam pendekatan komunikatif masih kurang diperhatikan. Hal ini dikarenakan mayoritas warga Indonesia masih lebih mementingkan dan memerlukan keterampilan membaca dibandingkan dari keterampilan berbicara. ${ }^{12}$

Pada hakikatnya metode eklektik dalam pembelajaran bahasa Arab tidaklah berbeda dengan bahasa asing lainnya, begitu juga adanya kelebihan dan kekurangan pasti juga ditemukan pada setiap metode yang mana memiliki kelebihan di satu sisi dan memiliki kekurangan di sisi lain. Oleh karena itu, hal ini perlu diantisipasi oleh pengajar bahwa maksud metode ini untuk bisa menjangkau dari semua segi.

Tidak ada yang berbeda antara metode eklektik dengan metode-metode lainnya. Metode ini juga mempunyai sisi kelemahan maupun sisi kelebihan. Salah satu kelebihannya yaitu apabila metode ini digunakan oleh seorang guru yang profesional dalam mengajar, serta mengetahui dan benar-benar mengusai bagaimana cara penggunaan metode dengan baik dan benar, maka sisi kelebihan dari metode ini akan semakin terasa dan proses pembelajaran berjalan dengan baik sesuai rencana dan tujuan pembelajaran. Namun apabila tidak didukung dengan profesionalisme seorang guru dalam proses pembelajaran, maka proses pembelajaran tidak akan berjalan dengan baik, dan metode yang digunakan hanya sia-sia saja. Di bawah ini adalah paparan secara terperinci mengenai kelebihan dan kekurangan metode pembelajaran eklektik, di antara lain sebagai berikut ${ }^{13}$ :

${ }^{12}$ Ahmad Rifa'i, Implementasi Thariqah Al Intiqaiyyah (Metode Eklektik) Pada Pembelajaran Bahasa Arab Di MTsN Kediri 1, Realita: Jurnal Penelitian dan Kebudayaan Islam. Vol. 13 No. 2 Tahun 2015. Hlm. 167.

${ }^{13}$ Radliyah Zaenuddin, Metodologi dan Strategi Alternatif Pembelajaran Bahasa Arab (Yogyakarta: Pustaka Rihlah Group, 2005). Hlm. 44. 
1. Kelebihan Metode Pembelajaran Eklektik

a. Metode ini merupakan metode pelengkap dari metode-metode sebelumnya.

b. Pembelajaran lebih efektif, menarik dan bervariasi.

c. Metode ini mengembangkan keaktifan, keefektifan dan keterampilan pelajar dalam belajar, dan membuatnya lebih mudah berinteraksi dengan yang lainnya dan tidak cepat bosan.

d. Kemampuan para pelajar dalam menggunakan bahasa asing dipandang lebih merata dan maksimal.

e. Guru lebih bersemangat dan energik dalam proses pembelajaran.

f. Penyampaian materi-materi yang diajarkan lebih efektif, dan suasana belajar mengajar di kelas lebih aktif dan kondusif.

2. Kekurangan Metode Pembelajaran Eklektik

a. Terbatasnya waktu yang digunakan dalam penerapan metode ini. Dikarenakan metode ini masih membutuhkan waktu yang relatif lama daripada metode-metode lainnya, serta terkendala dengan waktu pembelajaran bahasa Arab yang relatif sangat terbatas, terkecuali sekolahsekolah tertentu.

b. Metode ini membutuhkan guru yang cerdas, terampil dan dinamis dalam berbagai bentuk pengajaran. Tidak semua guru sanggup untuk melakukan serangkaian kegiatan yang begitu banyak dan bervariasi.

c. Lebih menuntut adanya guru yang serba bisa dan energik.

Dikhawatirkan dalam menggunakan metode ini, terdapat kegiatan pembelajaran yang begitu banyak yang akan membuat siswa kejenuhan dalam belajar. Kelebihan dan kekurangan sebagaimana dijelaskan di atas memberikan informasi kepada pengajar untuk mempertimbangkan pada materi atau bagian apa metode itu secara tepat dipergunakan dan dalam keadaan apa perlu disiapkan untuk melakukannya. 


\section{Kesimpulan}

Metode eklektik yang merupakan metode gabungan atau metode campuran pada hakikatnya memiliki beberapa penamaan yaitu: thariqah Mukhtarah, thariqah Taulifiyah, thoriqah Intiqa'iyyah, dan thariqah Mudzawijah. Metode ini muncul sebagai bentuk penggabungan dari metode-metode yang sudah ada sebelumnya. Metode elektik dikembangkan berdasarkan asumsi, bukan berdasarkan linguistik ataupun psikologi. Metode ini mempunyai tujuan yang ingin dicapai, yaitu tujuan dari beberapa metode yang dipilih dan digabungkan, sehingga keterampilan bahasa bisa terkumpul semua dalam metode ini.

Kelebihan dan kekurangan dari suatu metode dapat diketahui setelah mengimplementasikannya, karena kelebihan dan kekurangan suatu metode tidak bisa diukur tanpa mengimplementasikannya. Begitu juga dengan metode eklektik masih mempunyai kelemahan dan kelebihan pula. Dapat dikatakan menjadi sempurna jika seorang guru menguasai penerapan dalam penggunaan metode yang digunakan. Dan jika seorang guru menggunakan metode ini semaunya saja, maka proses pembelajaran tidak berjalan dengan baik.

\section{Daftar Rujukan}

Effendy, Ahmad Fuad. (2005). Metodologi Pengajaran Bahasa Arab. Malang:

Misykat,

Hardiyanti, Putri. (2014). Metode Pembelajaran Elektik. Padang: Nayla Amirah.

Hermawan, Acep. (2011). Metodologi Pembelajaran Bahasa Arab. Bandung: PT Remaja Rosdakarya,

Nurbayan, Yayan. (2008). Metodologi Pembelajaran Bahasa Arab. Bandung: Zein Al Bayan.

Rahman, Anwar Abd. (2011). Pengajaran Bahasa Arab dengan Metode Eklektik. Jurnal Adabiyah Vol. 11 No. 1 Tahun 2011

Raswan. (2018). Pengaruh Metode Pembelajaran Eklektik Terhadap Hasil Belajar Bahasa Arab Siswa. Arabiyat: Jurnal Pendidikan Bahasa Arab dan Kebahasaaraban Vol. 5, No. 1 Tahun 2018 
Rifa'i, Ahmad. (2015). Implementasi Thariqah Al-Intiqaiyyah (Metode Eklektik) Pada Pembelajaran Bahasa Arab Di MTsN Kediri 1. Realita: Jurnal Penelitian dan Kebudayaan Islam Vol. 13 No. 2 Tahun 2015

Sumardi, Muljanto. (2007). Pedoman Pengajaran Bahasa Asing. Surabaya: CV. Ilmu Surabaya.

Taringan, Henry Guntur. (1993). Strategi Pengajaran dan Pembelajaran Bahasa. Bandung: Angkasa.

Zaenuddin, Radliyah. (2005). Metodologi dan Strategi Alternatif Pembelajaran Bahasa Arab. Yogyakarta: Pustaka Rihlah Group. 